\title{
Advancing Sustainability in Private Higher Education through Quality Assurance: A Study of Two Malaysian Private Universities
}

\author{
Siew Fun Tang ${ }^{1} \&$ Sufean Hussin ${ }^{2}$ \\ ${ }^{1}$ Teaching and Educational Development, Taylor's Business School, Taylor's University, Malaysia \\ ${ }^{2}$ Department of Educational Management, Planning and Policy, Faculty of Education, University of Malaya, \\ Malaysia \\ Correspondence: Siew Fun Tang, Teaching and Educational Development, Taylor's Business School, Taylor's \\ University, Malaysia. Tel: 60-3-5629-5293. E-mail: siewfun.tang@taylors.edu.my
}

Received: June 12, 2013 Accepted: July 9, 2013 Online Published: August 30, 2013

doi:10.5539/ass.v9n11p270 URL: http://dx.doi.org/10.5539/ass.v9n11p270

\begin{abstract}
This study investigated the motivational constructs expressed by the stakeholders of two private universities in Malaysia and examined how these constructs help in advancing sustainability of the universities through quality assurance. Results were based on the findings from interviews and analysis of the academic programme administrator survey results. The findings revealed that the motivations for the two private universities to implement quality assurance policy can either be extrinsic or intrinsic and they differ according to their institutitonal mission and goals. However, three motivations seemed to be in congruence for the two universities. They were compliance to the Malaysian Qualifications Agency's requirements, competitiveness in higher education industry and internal continuous improvement which indicated important elements for the private institutions to remain self-sustained in the increasingly challenging industry.
\end{abstract}

Keywords: quality assurance, Malaysia, private universities, higher education, sustainability

\section{Introduction}

Private higher education in Malaysia has undergone extensive changes in response to the market needs and demands. In fact, the private higher education has evolved more rapidly than the public system and it may be considered as supplementing and complementing the public higher education system (Yahya Ibrahim, 2002). The Malaysian government encouraged the privatisation of higher education in order to provide expanded access to higher education and resulted local public and private corporations, foreign universities, multi-national companies, and transnational corporations seeing Malaysia as a lucrative market for higher education. Many self-financed academic programmes at the tertiary level have mushroomed. In short, higher education in Malaysia has become a business and burgeoning market that earns revenue (Tan, 2002). The enrolment numbers in higher education from 2002-2007, gathered from the Ministry of Higher Education shown in Table 1, indicate that private higher education institutions are capturing $40-50 \%$ of the market share.

Table 1. Number of higher education enrolment 2002-2007 by type of institution

\begin{tabular}{lllllll}
\hline & 2002 & 2003 & 2004 & 2005 & 2006 & 2007 \\
\hline Public Higher Education & 281,839 & 294,359 & 293,978 & 307,121 & 331,025 & 382,997 \\
Private Higher Education & 326,458 & 343,881 & 348,989 & 283,671 & 349,937 & 391,553 \\
\% of total higher education & $49.1 \%$ & $49.3 \%$ & $48.7 \%$ & $42.1 \%$ & $45.2 \%$ & $44.8 \%$ \\
Others* & 56,105 & 59,916 & 73,327 & 83,707 & 93,318 & 98,688 \\
Total & 664,402 & 698,156 & 716,294 & 674,499 & 774,280 & 873,238 \\
\hline
\end{tabular}

* includes polytechnics (certificate and diploma levels) and community colleges (certificate level only)

Source002E MoHE Malaysia (2010) 
Interestingly, the growth in private sector resulted in universities have become larger and more specialized, causing them to assume more diverse roles (El-Khawas et al., 1998). In most countries including Malaysia, the private higher education institutions are privately funded; they do not depend on the government for funds like the public universities do. Thus, they are increasing seeking opportunities to serve the business and the industry needs to seek more funding or simply to strengthen their involvements and contributions to the local and global community. The current quality assurance (QA) systems adopted in most countries may not support this issue. Even though Malaysian QA system in higher education has evolved and has established its national QA system but like many developing countries, the approach is "borrowed" from the developed countries. Since 2007, Malaysia has adopted a single QA system to implementing the Malaysian Qualifications Framework (MQF) with the aim of enhancing internal QA in both the public and private higher educations. It is also aimed to encourage effective engagement of stakeholders. Ultimately, the goal is to grant accreditation with continuous quality improvement approach.

The Malaysian QA system comprises of External QA (EQA) and Internal $Q A$ (IQA). EQA refers to the actions of the Malaysian Qualifications Agency (MQA) in assessing an institution's operation or that of its programmes in order to determine whether it is meeting the standards that have been agreed on. The Malaysian EQA system adopted a voluntary nature whereby higher education providers may apply to undergo EQA. They could decide for themselves whether they wish or not to join the process and adhere to the set quality model. On the other hand, IQA refers to each institution's or programme's policies and mechanisms for ensuring that it is fulfilling its own purposes as well as the standards that apply to higher education in general or to the profession or discipline in particular. The importance of QA in private higher education and the roles of private higher education in developing the country's higher education is undeniable. The way the private higher education institutions operationalise the QA mechanism may vary from institutions to institutions. However MQA provides guidelines for implementation with the aims to increase public confidence in Malaysian higher education and for the private higher education institution to assist the government in developing human capital with first class mentality, create a conducive environment that foster academic and institutional excellence, achieve international recognition and sustainability to the Malaysian Higher Education System and position Malaysia as a hub for higher education in the region and internationally.

One common perception is that most private higher education institutions are entrepreneurial-focus and often, do not involve actively in assisting the government in developing the country's higher education. Taylor et al. (1997) queried the motivation for the development of public policies in education if private sector activity is motivated largely by profit. However, in Malaysia, the contribution by the private providers to the higher education excellence in the country was acknowledged by the Minister of Higher Education (Mohamed Khaled, 2010) and much effort has been put in by the government to assist the private higher education to align to the national educational goals. As the provision of higher education is becoming more diversified and at the same time globalisation creates the need for more transparency and standardisation for qualifications to be assessed, there has been a shift in how the private providers see QA in higher education. Research involving the private sector is always difficult due to their nature of business. In general, private higher education is subjected to a trade- off between quality and quantity as the providers are profit-making institutions. Geiger (1986) argues that the constraints of limited finance and resources force private higher education institutions to become primarily teaching institutions. However, as the competition among the private higher education institutions in recruiting students, especially the international students, becoming more intense, there has been a change in the way private higher education institutions are managed. Due to their credibility in producing quality graduates, they are now regarded as quality education providers. Hence, some of these private universities become reputable and applauded for accountability and quality teaching and learning. They are now more open to share their "success stories" and this study took the opportunity to explore this challenging market segment of higher education. The number of research done in the area of QA in private higher education is handful. The recent two were from Zainudin H. A. \& Mohd. A. C. M., (2005) who focused on assessments and Morshidi Sirat et al. (2006) who studied enhancing quality of faculty. The findings from this study will bring significance to the body of literature.

\section{Data Sources and Methodology}

Case studies were conducted on two private universities over a period of six months. In each case, semi-structured interviews were conducted to various key stakeholders in QA implementation and a survey was administered to all academic programme administrators. Analysis of each case is divided into two sections. First, the interview findings will be presented in the order of introductory profile of the institution and the interview participants, and their motivations for implementing QA. The introductory profile of the institutions and the 
participants provides glimpses of the institution's background and participants' dispositions towards certain issues. Most of the participants were stakeholders who were actively involved and familiar with the inner lives of the institution. Hence they were able to provide an "official" view of the institution, or at a perspective reflecting their position and interests within the institution. In particular, the administrators and lecturers were admirably self-critical and honest about their responses which revealed some distinctive factors that influence the extent of implementation process. Second is the analysis of the administrator survey which will be presented in the order of demographics description of the survey participants, reliability of the questionnaire and followed by responses on their motivation to implement QA. The descriptive analysis of the academic programme administrator survey is intended to compare how administrators of the two different institutions view some predetermined QA policy implementation issues in their institutions. Taking a sample which is representative of the population and allowing the administrators to respond anonymously to the questionnaire increased the likelihood of accurate answers. According to Gay et al., (2006), survey research at its best can provide valuable data. The researcher had taken steps to ensure that the survey was properly planned and executed.

\subsection{Case Studies}

\section{Case I: Institution A}

Institution A was a university owned privately by an organisation that was a leading multi-industry conglomerate based in Kuala Lumpur, Malaysia. It was established in 1980s (exact year not included to protect the anonymity of the institution) as a college. After slightly more than a decade, it then evolved into an international college to reflect its increasing international focus and was accorded university college status two years later. Institution A received its university status after five years, in a mere 19 years since its establishment. Now it has three campuses spread out in three states with a combined student population of 8000 students. One distinctive characteristic of its academic curricular was that all students at Institution A had to undergo industrial training in industry partner organisations to enhance their employability. With this innovative integration of classroom learning with workplace training, students will have six to eight months of work experience by graduation and stand ready for full-time employment.

Twelve stakeholders from Institution A participated in the interviews. They included the Chancellor, Registrar, QA Vice President, Dean from the Health Sciences School, Head of Department from the Engineering School, a senior lecturer from the Computing School, a student, an alumni, three parents and an employer who was the Senior Manager, Marketing and Technical Support from a private company in the Life Science industry. Specific job titles were changed to protect the anonymity of the individuals but the re-assigned job titles reflected the nature of work. The participants were selected purposively due to their nature of work, stakeholder positions and their involvement in implementing QA policy. Hence, they were able to provide greater insights into the inquiries of this study. All the interviews were face-to-face except for the alumnus who was interviewed via online because he was doing his postgraduate study in Kyoto, Japan.

\section{Case II: Institution B}

Institution B was an established and reputable private institution which has prepared successful graduates for higher education through a comprehensive range of internationally recognised courses ranging from pre-university to diploma and degree programmes. From its humble beginnings as a college in 1960s, Institution B was officially granted 'University College' status in 2006. It was rated as 'Tier 5: Excellent' by the MoHE in the 2009 MQA Rating System for Malaysian Higher Education Institutions (SETARA '09), which measures the quality of teaching and learning at the undergraduate level in universities and university colleges in Malaysia. Soon after that it was awarded the 'University' status in 2010.

There were nine stakeholders from Institution B who participated in the interviews. They included the Vice Chancellor, Quality Manager, a lecturer from the Communication School, the Business Management Stream Coordinator, the Dean from the Management School, a current student, an alumni, a parent and an employer who was a Graduate Recruiter Manager from a private bank. All the participants were every involved and familiar with the inner lives of the institution, hence they are able to provide an "official" view of the institution, or at a perspective reflecting their position and interests within the institution.

\subsection{Academic Programme Administrator Survey}

The questionnaire used for the Academic Programme Administrator Survey was in the form of self-report that required individuals to respond to a series of statements about themselves. It was aimed to determine the reasons or motivations for implementing QA in their respective institutions and describe the way things were especially concerning the implementation extent of QA policy. However, the latter will be reported in another paper. In total, 
62 administrators responded to the survey with 25 (response rate 51.0\%) and 37 (response rate 94.9\%) administrator respondents from Institution A and Institution B respectively. Allowing the administrators to respond anonymously to a questionnaire would increase the likelihood of accurate answers. However, one limitation was that the researcher had limited opportunity to explain to participants who were filling out a questionnaire on what a particular question or word really means. According to Gay et al., (2006), survey research at its best can provide valuable data. Hence, the study was planned and executed with proper care. The researchers sent follow-up reminders through emails, telephone calls and personal visits to the institutions to ensure high response rate. Other attempts included assuring respondents of the anonymity of response, enclosing a self-adhesive return envelope, and allowing sufficient response time.

\section{Research Findings}

\subsection{Findings from the Interviews}

\section{Case 1: Institution A}

The mission of Institution A was to be more responsive to societal needs for capable graduates, equal education opportunities, and lifelong learning and knowledge development through research and innovation. The Quality Policy stated that the management and staff were highly committed to quality and excellence in the provision of all academic programmes and services, to be performed with dedication and standards to customers' satisfaction and surpassing their expectations. To earn recognition as an institution of outstanding quality, Institution A had designed, implemented and constantly developed its QA system. The Registrar admitted that the main reason for such effort was to comply with the QA policy and standards set by the Ministry of Higher Education (MoHE). Like it or not, all the private higher education institutions were governed by the Private Higher Institution Act (Act 555) which depicted the power and role of the minister and MQA. The MoHE had put in place auditing mechanism such as Malaysian Universities Rating System (SETARA), Academic Performance Audit (APA) and Code of Practice for Institution Audit (COPIA) which spelt out mandatory requirements that higher education institution have no choice but to comply.

According to QA Vice President who headed the QA department in Institution A, compliance was a major task in Institution A because the Institution offered many professional programmes that needed to be in compliance with the requirements of the professional bodies such as the Malaysian Medical Council, Malaysian Pharmacy Board, Malaysian Institute of Architects, Board of Engineers Malaysia and Malaysian Nursing Board. He added, "We need to keep on our toes to make sure we are compliance if not we will have a lot of difficulties because our students will be jeopardised when come to practice, especially medical, pharmacy and all that or getting license to practice, for nursing for that matter. Like it or not, we have to be very much compliance-based". Hence, his department shouldered the major role of ensuring all programmes were complying with the necessary requirements in order to get accredited. He was proud to inform that to-date, Institution A had been $100 \%$ successful in getting full accreditation for all its programmes which were due for accreditation. He further emphasised that compliance was like a chasing game. He quoted, "It is not easy because rules change all the time. Compliance five years ago is different compliance now". He gave an example on students' entry requirements, "The government or the technical committees in MQA, or relevant professional bodies already revised the entry requirements. So whatever compliance last year, it changed now. Maybe after three years, it changes again".

He then explicated that being a fairly young university, they would not want to neglect on quality enhancement having complied mandatory requirements. With the help of a foreign consultant, who was an expert in the area of quality globally, they continuously looked at the QA best practices as well as learning and teaching methodologies. He added, "We are also pushing the government to unleash us ... That is important because we should be open to do things so long as we have the control ... and ... do the things as best practice". According to him, "That is the whole quality sector that we are looking at, not just compliance and stop there. We want to do a lot more". He acknowledged that the higher education industry was moving forward because the government wanted Malaysia to be the international hub of higher educational excellence competitive in the global market, targeted to attract 200,000 foreign students and at the same time, the government wanted the higher education institutions to be competitive as well. Since quality was one of the factors that people would look at when considering on the choice of university, higher education providers were required to raise standards to keep up with the intense competition as they were self-sustained private universities. The QA Vice President added, "We are quite open to go beyond the mandatory requirement when comes to education operation within Malaysia and so on because our target is within the next year or so, with the liberalisation policy in 2012, I am sure Malaysia is opening up doors to anybody to come in". He quoted another example, "When we open doors to foreign universities coming into Johor Region, and we have John Hopkins coming... all these opening doors, it is 
going to be very far behind chasing them if you are not already exposed to whatever they are doing". He then cautioned that "you end up being moved an inch if you are forced to...or by act or regulation, by government enforcement, you will be moving in that sense instead of being part of learning community". Competition among universities has significantly increased, both on a national and international scale. Universities, private or public, are competing for students, staff, funding in terms of research grants for private universities, and reputation. The National SETARA rating system aims to intensify the competition and accelerate improvement. Even though it is not a ranking system, but it has made its contribution to the nation-wide comparison of universities. Education providers must move up and become excellence otherwise the market forces will make them obsolete as expressed by QA Vice President:

The point that I want to make is that a lot of walls are taken away [emphasised]. You better buck up, if not you are going to expose yourself to a lot of critics ...this kind of issues. ( $Q A$ Vice President, Institution A)

The expansion and diversification of Institution A has created a varied array of courses, programmes both on a national and international scale. External stakeholders such as students, parents and employers demand new kind of information and new approaches to QA management. Its registrar argued that accountability, compliance and internationalisation drives implementation of QA policy in Insitution A and defended that it is more of internal motivations than external motivations.

First thing is mainly to ensure that we are doing more than what is required so that when someone joins us they join us with a dream. They are depositing a huge amount of money because private education is not cheap. So, it is our own self-policy first [emphasised]. This is what we think. ... The fact that the government monitoring through the governing bodies or statutory, that is given, you have to comply. That shouldn't be affected. The other thing is that we are global, we are global corporate people. So being global corporate, we want to put ourselves on the map and the only way is people see you have systems in place already and you are actually walking the talk... we review programmes from time to time. All these ... I would say more because we have the obligation to deliver to best [emphasised]. And in order to deliver the best, we have to do all these. It is internal more than external. (Registrar, Institution A)

From the academic perspective, the Dean, School of Health Sciences regarded research as part of quality. She believes that the need for QA is due to the desire to generate new knowledge through research, to produce quality graduates, improve quality of staff and assure quality of students' experience while they were studying at Institution A.

Only when the staff and students are involved in research, the understanding what is the meaning of generating knowledge. I see research as very important. It is part of the quality...the quality of student learning experience as well as the academic staff that we have...I have been focusing on the research development because I believe this is very important to reflect the quality... When people talk about quality of a programme, they will eventually look at your output, the outcomes that you have. To me I believe in generating real graduates... Frankly speaking knowledge is something that people can have. It is most easy to gain attributes. But other types of attributes like critical analysis ability, communication skills, working as a team, have a very open mindset... I believe in generating graduates when they go out and work, the employer will say they have the right attitude, they are the right people. (Dean, School of Health Sciences, Institution A)

Her thoughts was shared by the QA Vice President who said the focus of QA and enhancement procedures was not just on maintaining the academic output standard of programmes but most importantly to assure the quality of their students' learning experience at Institution A.

In summary, Institution A implemented QA policy for several reasons, namely compliance to external QA policy and standards set by the MoHE and professional bodies; internal improvement; stiff competition among local and global universities; accountability; research development and assuring quality of their students' experience while studying at Institution A. The last reason is very much related to their mission.

\section{Case II: Institution B}

Institution B has expanded substantially especially in the last five years, after being granted the university college status. The responses from the participants indicated that many initiatives and changes were taking place 
to transform the insitution to a university, a status granted to Insitution B about a year ago. The Quality Manager gave a detailed explanation on the transition that took place and how it has directly or indirectly made Institution B embraced enthusiastically in the QA policy regulated by the government and developed their own internal QA practices. She explained:

Because of that status change [from College to University College], this institution has the power to award our own degrees ... it is actually very significant and important change of role and it is timely for us to look into our quality management system, our policies and procedures to develop a more comprehensive version to support our new status or our new role. At the same time, MQA released the code of practice and we started to revise our academic related policies and procedures to focus on both teaching and research. We are constantly reminded our role towards our country and society. Employers are becoming more important stakeholders from the teaching and programmes offering aspects. Being a new and young university, our research tends to focus on applied research rather than the basic or foundation research. Having partnership relationship with the industry is important because we can help them to solve problem and apply our result. They also became an important stakeholder in terms of research. We have our government having stronger and stronger influence (laugh) which is also important. We can understand because of our role to support our country's aspiration towards knowledge economy which we need to have two aspects; we need to have student innovative mind, the first class mind set and on the other hand, we also need expertise in the university; the academician and researchers on both the human resource part, and the invention and research aspect. That has implications on our strategic planning. (Quality Manager, Institution B)

The interview with Quality Manager revealed that Institution B has no intention to be an univeristy initially but intention came when the government announced its intention for Malaysia to become an education hub which would attract more international students. This business opportunies sparked the initiative of becoming a university college and subsequently a university as revealed by the Dean from the Management School. Being a very senior staff in the institution, she related to past experience whereby colleges were only allowed to start $1+2$ (first number represents the number of years the student spend at home country and second figure refers to the number of years spend abroad at partner university) twinning programmes and only institutions with certain years of experience running $2+1$ or $1+2$ twinning programmes were allowed to run $3+0$ franchised programmes if equipped with sufficient academic staff and facilities. She also pointed that similar conditions for experience and resource were imposed when private colleges were upgraded to 'university college' and subsequently to 'university' status. In Malaysia, only well-established university colleges were invited to apply for the 'university' status. To achieve that, Institution B sought the help of one of the top university in Australia in 2000 to be their consultant to move the institution to the university college direction. During that time, systems and processes in particular QA practices were established. To realise the ambition of becoming a university, Institution B knew that they needed to make adjustments to their current QA set up to align to the government initiative and policies in order to comply with the necessary standards. As acknowledged by the MQA Director in an interview, the quality in a university was always perceived to be well above of those in university colleges or colleges.

The Vice Chancellor summed up the extrinsic motivations for Institution B in implementing QA policy as to be competitive, competent and recognised in the higher education industry. On the other hand, the Dean of Management School acknowledged that the intrinsic motivations for implementing QA policy was to ensure that the systems and policies were well in place for consistency of standard, smooth running of institution as well as effective leadership succession. The following interview excerpts give evidence to what was said:

It is for competitive advantage and also to give people high level of competence and also for recognition. Of course this is for competitive advantage. You want to get more students, more value and more money...We make sure our programmes are good. There is high quality and there is no hiccup. We make sure if anyone who takes over even in the future, there is no problem because when a policy is in place, there will be consistency and there won't be any problem. It is also to look at the quality of students...the results, accuracy of the results and so on.... the students as well as the lecturer. For example, via the internal moderation, the lecturer would be able to understand the expectations of the university and standards of what they have set. Also there is consistency and it is good to look at the latest updates of the subjects and so on. (Dean, School of Management, Institution B) 
She acknowledged that widely recognised quality programmes would increase the flexibility for students to transfer to other university overseas. She also stressed that QA should be put in place for quality improvement and not only for compliance sake:

In my personal view, it is more for quality improvement. This is why I mentioned earlier that even though there was not governance in placed in the past, I actually took the initiative to start off QA processes. Whether we like it or not, in the establishment of a college or university college or university, this is one of the requirements. We talk about compliance. Whether we want to go for ISO certification or MQA or whatever, my personal view is that if any faculty try to comply with the rules by following the procedures but do not do a proper QA implementation, I think is meaningless. (Dean, School of Management, Institution B)

In summary, the main motivation for implementing QA policy in Institution B identified by the participants was the aim of the institution to be granted the "university" status in order to remain competitive in the higher education business. Other motivations include internal improvement, consistency in standards, practices and outputs, and international recognition to facilitate students' mobility. Consistency was also to ensure expectations were met and smooth running of operations as well as to facilitate leadership succession.

\subsection{Findings from the Academic Programme Administrator Survey}

The response rate from Institution A was 51.0\%. Barbie (2007, p. 262) attested that "A review of the published social research literature suggests that a response rate of at least 50 percent is considered adequate for analysis and reporting. A response of 60 percent is good; a response rate of 70 percent is very good." Hence, the administrator survey results from Institution A are report drivable. According to Dillman (1991), a low response does not necessarily entail non-response error because those who respond may not differ in any measurable way from those who do respond. In other words, a representative sample in which the non-respondents do not differ from the respondents is more important than a high response rate. To determine the extent of non-response error, Israel (1992) recommended finding out the reason(s) why people did not respond. If there is no obvious reason, it is reasonable to inference. Feedback by the research centre staff revealed that most of the non-respondents were on their year-end vacation and were very difficult to reach. This could not be avoided because the researcher was only allowed to conduct her study in Institution A within that period and was told that most of the administrators would be busier at a later time as the university's new semester commences at the beginning of the following year.

As a strategy in addressing non-responses, Israel (1992) recommended that data in hand on respondents and non-respondents to be compared to see if differences exist. In this study, the composition of respondents and non-respondents with regards to gender and job category were examined. The information gathered from the list of administrators given by the institution revealed that the non-respondents comprise 11 male and 13 females. They have both the administrative and academic responsibilities and hold positions as Dean, Associate Dean, Head of Department or Programme Leader. Based on these information, both the respondents and non-respondents groups have almost similar composition of female and male, and all of them belongs to the same job category (administrative and academic). Hence, we can reasonably assume the absence of response bias.

On the contrary, the researchers were given the permission to approach the administrators personally in Institution B. They were able to administer the questionnaire to close to $90 \%$ of the administrator population whereby the $10 \%$ were either unreachable or they were new to the organisation. Due to extensive effort and great patience by the researcher in following up with the participants, the response rate for institution A was $94.9 \%$ (37/39). The two participants who did not return the completed questionnaire decided to withdraw from the survey as they were too busy with their work. Hence, we could conclude that the response group was representative of the whole population from Institution B and that the results are generalisable. Overall, the response rate for the administrator survey for both the institutions was $70.5 \%(62 / 88)$.

The gender composition in the two institutions differed greatly. $44.0 \%$ and $70.3 \%$ of the respondents from Institute A and B respectively were female. Taking the non-respondents into consideration for Institution A, the administrator group had almost equal number of female and male. However, Institution B was female dominant. 


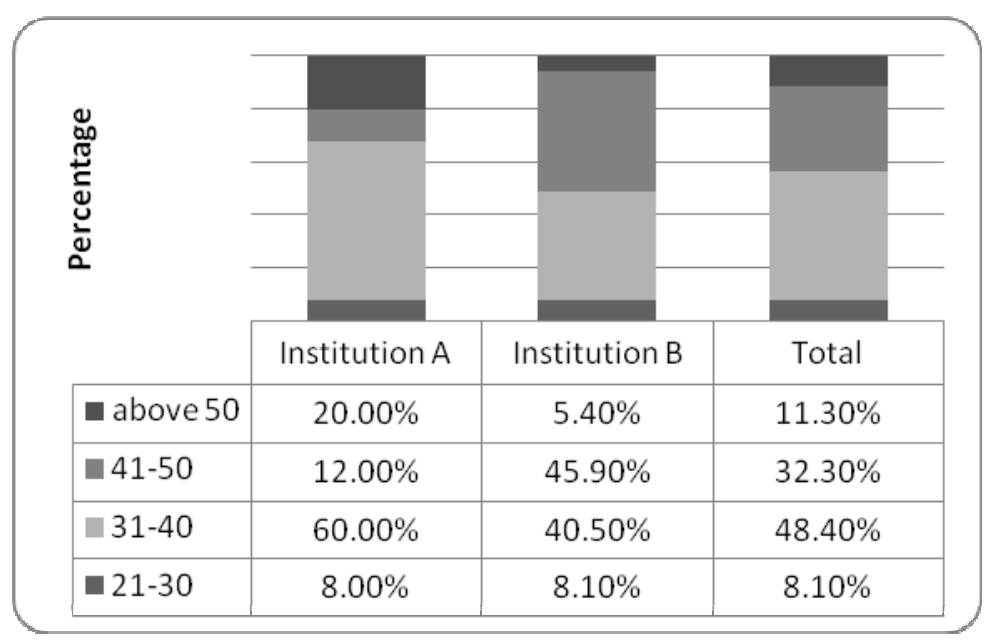

Figure 1. Age distribution of the administrator respondents

Figure 1 above indicates that most of the administrator respondents from Institution A were between 31-40 years old while in Institution B, they were in a wider age range, i.e. 31-50 years old. As for age 50 and above, Institution $\mathrm{A}$ had $20 \%$ composition of the respondents compared to only $5.4 \%$ in Institution B. In other words, Institution $\mathrm{A}$ had a combination of very senior and moderate young administrators.

Another notable difference between the administrator respondents in Institution A and Institution B was their number of service years. As illustrated in Figure 2, while almost half $(48.0 \%)$ of the administrator respondents from Institution A had service years of 3 or fewer, half (48.6\%) of the respondents from Institution B had been with the organisation for at least 7 years. Substantial difference of $8 \%$ and $35.1 \%$ of the respondents from Institution A and Institution B respectively had served their organisation for at least 10 years. In other words, Institution B had longer service administrators compared to Institution A, indicating that staff loyalty was evident among administrators in Institution B. More newly joined administrators in Institution A may be indicative of higher turnover or they were hired because of the institution's recent expansion.

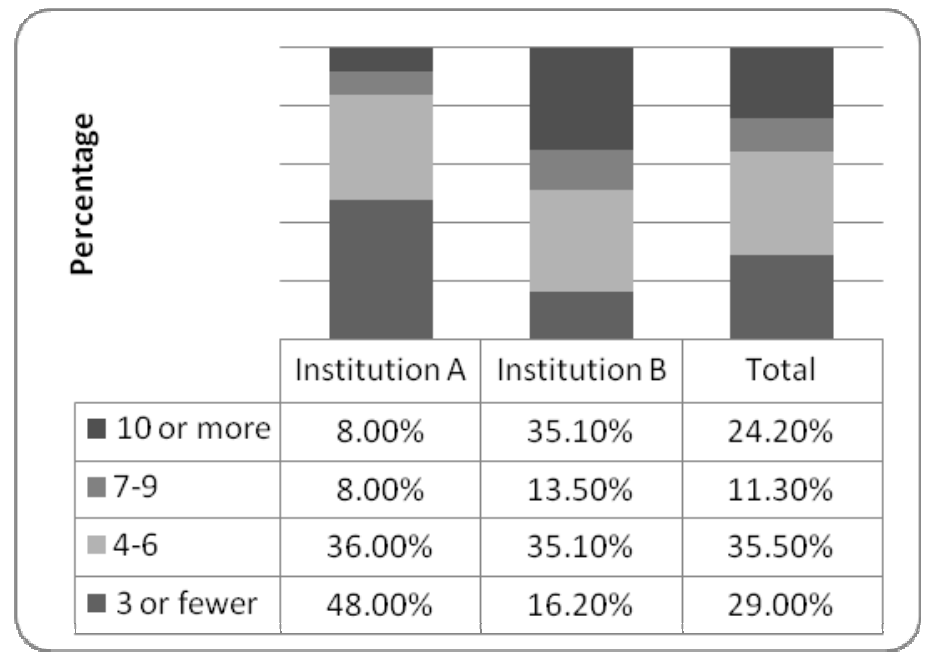

Figure 2. Years of service of the administrator respondents

With regards to job category, all the administrator respondents from Institute A had both the administrative and academic (inclusive of teaching) responsibilities, while only $59.5 \%$ of the administrators from Institution B said that they were in that category. $24.3 \%$ administrator respondents from Institution B do purely administrative duties and they included deans especially from the non-science disciplines and administrative managers. Stream (or subject) coordinators were mainly the administrators in Institution B who handled academic matters only and work closely with the academics. They comprised $16.2 \%$ of the respondents from Institute B. The positions or job titles of administrators in the two institutions may be the same but the responsibilities in terms of academic 
and administrative work may vary. From the organisation structure, Institution B had a lot more administrative support staff than Institution A.

Respondents were asked to choose the reason(s) for implementing QA in their institution. Five options namely 'compliance', 'improvement', 'accountability', 'recognition/reputation' and 'others' were given. Respondents may choose more than one option and were required to write the specific reason if "others" was their choice.

Table 2. Reasons for quality assurance in higher education

\begin{tabular}{ccccc}
\hline & & \multicolumn{2}{c}{ Motivations (reasons) for QA Implementation } \\
& Compliance & Improvement & Accountability & Recognition/ reputation \\
\hline Institution A & $56.0 \%$ & $80.0 \%$ & $60.0 \%$ & $52.0 \%$ \\
Institution B & $75.7 \%$ & $75.7 \%$ & $62.2 \%$ & $59.5 \%$ \\
\hline
\end{tabular}

The perceived reason was not exclusive because the respondents could choose more that one response. The results were summarised in Table 2. In general, administrator respondents from the two institutions felt that desire to improve within the institution was the main reason they implemented QA policy. For Institution A, the second reason was 'accountability', followed closely by 'compliance' and 'recognition or reputation'. The results from the Administrator Survey were consistent with the responses from the interview participants as described in the previous section. As mentioned earlier, Institution B was in the process of getting "university" status during the data collection stage for this study. Hence, it is unsurprisingly that "compliance" was one of the main motivations for implementing QA policy in Institution B compared to 'accountability' and 'recognition or reputation'. During that time, effort for compliance to the requirements set by MoHE was intensified. The results from the Administrator Survey concur partly with the responses from the interview participants as described earlier.

\section{Concluding Comments}

Convergence in extrinsic motivations for implementing QA policy in the two case universities was unsurprising. Both were large private universities, wanting to stay competitive and be the market leader in the industry. The Malaysian EQA system adopted a voluntary nature whereby higher education providers may apply to undergo EQA. They could decide for themselves whether they wish or not to join the process and adhere to the set quality model. If the programme fulfilled the standards and criteria, a special status was acquired through accreditation in the EQA system, which would give them an advantage in a competitive environment in finding students and funding. Section 81 of the MQA Act 2007 (Act 679) provided that MQA shall establish and maintain a national register known as the Malaysian Qualifications Register (MQR), made available online for reference to all stakeholders, containing programmes, qualifications and higher education providers accredited under the Act that conform to the MQF. The MQR were found to contain information on the credit requirements of each qualification or programme, and thus facilitate the credit transfer process from one level to another. Such transparent and accountable move was intended to enhance public confidence of higher education qualifications. The desire to be listed in the MQR will definitely create a movement through which if not all, at least the majority of institutions to be pulled into the system. Since QA in higher education was regulated by the MoHE, compliance to the standards and objectives set by MQA were expected in order for study programmes to be accredited. The private higher education institutions including the two case universities had no choice but to comply with these requirements. This finding concurs in parts to the findings of Brennan and Shah (2000). In analysing the national quality agency case studies carried out in a project sponsored by the Organisation for Economic Co-operation and Development (OECD) programme on Institutional Management in Higher Education, they found out that, largely, the motivations for the establishment of QA system stemmed from a need to respond to the creation of an external quality agency, and due to institutional change as well as new management needs. They suggested that external QA could provide an impetus for the creation of internal QA processes which then became beneficial to administrators and managers.

Furthermore, the motivations for implementing QA policy were also due to the pressure for the institutions to become more formally accountable with the changes facing private higher education such as massification, diversification, increase in research grants for private higher education and allocation of government sponsored students to study in the privation higher education institutions including the two case university. Nowadays, quality has become one of the factors that people would look at when considering on the choice of university. 
Quality in higher education has been defined in many diverse ways and its importance is undeniable. Hence being self-sustained universities, private higher education providers including the two case universities need to raise standards to keep up with the intense competition. Becher and Kogan (1992) acknowledge market competition plays an important role alongside with government and academic or collegial interests in facing quality management issues. As mentioned above by Brennan and Shah (2000), IQA and EQA are interlinked. Hence, internal improvement was expected to be one of their intrinsic motivations in implementing the QA policy. The two other intrinsic motivations from the findings were different. Institution A wanted to assure the quality of its students' university experience in line with an espoused goal of its mission in order to create a differentiating factor for its students. Institution B, on the other hand, wanted to ensure consistency in procedures because the standardisation was believed to be able to facilitate effective management.

\section{References}

Barbie, E. (2007). The Practice of Social Research (11th ed.). Belmont, California: Thomson Wadsworth.

Becher, T., \& Kogan, M. (1992). Process and structure in higher education (2nd ed.). London: Routledge.

Brennan, J., \& Shah, T. (2000). Managing Quality in Higher Education: An International Perspective on Institutional Assessment and Change. Organization for Economic Co-operation and Development (OECD).

Dillman, D. A. (1991). The design and administration of mail surveys. Annual Review of Sociology, 17, 225-249. http://dx.doi.org/10.1146/annurev.so.17.080191.001301

El-Khawas, E., DePietro-Jurand, R., \& Holm-Nielsen, L. (1998). Quality assurance in higher education: Recent progress; challenges ahead. Washington D. C.: The World Bank.

Gay, L. R., Mills, G. E., \& Airasian, P. (2006), Education research: Competencies for analysis and applications (8th ed.). New Jersey: Pearson Prentice Hall.

Geiger, R. L. (1986). Public and private sectors in higher education: Structure, function, and change in eight countries. Ann Arbor: University of Michigan Press.

Israel, G. D. (1992, November). Sampling Issues: Non-response. Programme Evaluation and Organizational Development, IFAS. University of Florida. PEOD-9. Retrieved March 8, 2011, from http://edis.ifas.ufl.edu/pdffiles/PD/PD00800.pdf

Mohamed Khaled, N. (2010, March 30). The New Straits Times.

MoHE Malaysia. (2010). JADUAL 1.2: JUMLAH ENROLMEN PELAJAR DI INSTITUSI PENGAJIAN TINGGI, TAHUN $2002 \quad-\quad 2007 . \quad$ Retrieved May 20, 2010, from http://www.MoHE.gov.my/web_statistik/statistik_pdf_2008_05/data_makro_1-2.pdf

Muhamad Jantan, C., Jantan, C. H. C., Suhaimi Shahnon, S. S. (Eds.) (2006). Enhancing Quality of Faculty in Private Higher Education Institutions in Malaysia. National Higher Education Research Institute (IPPTN).

Tan, A. M. (2002). Malaysian private higher education, globalisation, privatisation, transformation and marketplaces. London: Asean Academic Press.

Taylor, S., Rizvi, F., Lingard, B., \& Henry, M. (1997). Educational policy and the politics of change. Routledge.

Yahya, I. (2002). The growth and development of private higher education in Malaysia from MAPCU's perspective. In H. Sufean (Ed.), Revitalising education: some prospective policy innovations, 55-68. Kuala Lumpur: Utusan Publications and Distributions Sdn Bhd.

Zainudin, H. A., \& Mohd Azuhari, C. M. (2005). Quality assurance in higher education: Serqual model as the alternative measuring instrument for service quality performance in Malaysian higher education. In Proceedings of National Conference on Tertiary Education (NCTE). Pusat Penerbitan Universiti (UPENA), Universiti Teknologi MARA.

\section{Copyrights}

Copyright for this article is retained by the author(s), with first publication rights granted to the journal.

This is an open-access article distributed under the terms and conditions of the Creative Commons Attribution license (http://creativecommons.org/licenses/by/3.0/). 